conductor immediately prolonged, and to have adcled to it a large terminal plate of copper, which was to be completely submerged in the sea. The obvious convenience of a chain as a prolongation of the conductor caused the authorities in Ireland to propose it, but I was obliged to veto the adoption of the chain. The contact of link with link is never perfect. I had, moreover, beside me a portion of a chain cable through which a lightning discharge had passed, the electricity in passing from link to link encountering a resistance sufficient to enable it to partially fuse the chain. The abolition of resistance is absolutely necessary in connecting a lightning conductor with the earth, and this is done by closely embedding in the earth a plate of good conducting material and of large area. The largeness of area makes atonement for the imperfect conductivity of earth. The plate, in fact, constitutes a wide door through which the electricity passes freely into the earth, its disruptive and damaging effects being thereby avoided." Prof. Tyndall understands that lightning conductors are frequently set up without any terminal plate whatever. It is said that the Bishop of Winchester's palace at Farnham is "protected" in this way. If this is true, the Bishop will be interested to hear that the "protection" is "a mockery, a delusion, and a snare."

WE have received the twelfth Report of the Bradford Philosophical Society. This institution was revived two years ago, and we are glad to see from the Report that it has "a bright prospect of success." The Society is closely associated with a group of affliated Societies in Bradford, and it has been found that this plan works well. "The joint programme of the Societies," says the Report, "is one that reflects great credit on the town, and members of the Philosophical Society would do well to avail themselves (as their membership allows) of the various lectures and excursions of the united Societies. Members of the Society may be assured of a hearty welcome." The affiliated Societies are the Historical and Antiquarian Society, the Microscopical Society, the Naturalists' Society, the Scientific Association, and the Browning Society.

Lieut. Wissmann, the well-known African traveller, has arrived at Mozambique. He intends to proceed to Zanzibar on his way back to Europe.

THREE large packages containing rare plants and specimens from India have been received from Calcutta by the Keeper of the Ethnographical Department of the British Museum.

A sHock of earthquake was felt in Mexico at seven o'clock on Monday morning. The houses were shaken and the inhabitants much terrified, but no damage was done. The direction of the shock was from north to south. The shock was also felt at Chilpancingo, where two arches of an arcade in the main square were demolished, at Orizaba, Tlaltan, and Otumba.

A LARGE proportion of the salmon fry hatched out by the Severn Fishery Board at the new hatchery at Worcester this year are being reared by Mr. William Burgess in his ponds at Malvern Wells, pending their transference to the open river. It is worthy of note that the fry may be seen rising continually to the fly. Seeing that they inhabit the bottom of the river in their wild state and do not rise, this is rather remarkable. Their rate of growth does not seem to be so fast as that of other fish, although their present position is well suited to their requirements.

THE additions to the Zoological Society's Gardens during the past week include a Rhesus Monkey (Macacus rhesus) from India, presented by Miss Austin; a _- Capuchin (Cebus - ) from South America, presented by Mr. J. H. Williams; two Horned Lizards (Phrynosoma cornutum) from North America, presented by Mr. Maxwell Blackie; two Common Boas (Boa constrictor) from Dominica, W.I., presented by Mr. A. Nicholls ; Smooth Snake (Coronella levvis) from Hampshire, presented by Mr. Sidney G. Smith; a Lion Marmoset (Midas rosalia), a Peba Armadillo (Tatusia peba), two Blue-bearded Jays (Cyanocorax cyanopogon), an Ariel Toucan (Ramphastos ariel), three Bahama Ducks (Dafila bahamensis), a Laughing Gull (Larus atricilla) from Brazil, a Black-handed Spider Monkey (Ateles melanochir $\$$ ) from Central America, eight Blanding's Terrapins (Clemmys blandingi) from Michigan, U.S.A., purchased; two Hybrid Australian Ibises (between Ibis strictipennis and Ibis bernicri) bred in the Gardens.

\section{OUR ASTRONOMICAL COLUMN}

VARiable Star iN the Ring Nebula in Lyra-Herr Spitaler draws attention in the Astronomische Nachricten, No. 2800 , to the apparent variability of the small star near the centre of this well-known nebula. He had made himself pretty well acquainted with the nebula in September 1885, when he had sketched it, but was induced to examine it again last autumn from the note on the "ring-formed nuclets" discovered by means of photography, which Herr E. von Gothard had published in the Astronomische Nachricten, No. 2749. The interior of the ring nebula appeared with a low power to be covered with a faint curtain of light, which a high power showed to be of varying intensity, so that the interior had a faint flocculent appearance; a bright speck of light was also easily récognized midway between the centre of the nebula and the inner edge of the ring on the south-west side. In the eastern portion three faint stars were seen several times, but a fourth star seen by Prof. Vogel, and shown on the photographs of the Bros. Henry, could not be made out. But on July 25 of the present year, during the visit of Prof. Young to the Vienna Observatory, on the telescope being again turned to the nebula a small star was seen at the first glance a very little north-west of the centre, just as it is shown in the Gothard photograph, but a little fainter. The following night it was seen again, but not so distinctly. The star would therefore appear to be variable, and well worth watching. The evidence of Herr von Gothard's photograph, which shows it, whilst a faint star in the neighbourhood is not represented, seems to indicate that it is particularly rich in actinic light.

New Variable Star.-Mr. Espin announces in Circular No. 17 of the Wolsingham Observatory that the star Birmingham $54 \mathrm{x}$ is variable from $6.6 \pm$ to $8.0 \pm$. The star's place for I 887 is R.A. $20 h .9$ m. $17 \mathrm{~s}$; Decl. $33^{\circ} 22^{\prime} \circ \mathrm{N}$.

Discovery of a Comet. -Mr. W. R. Brooks, Red House Observatory, Phelps, New York, discovered a comet on August 24, 20h. 53m. G.M.T. Place of the comet, R.A. 8h. $33 \mathrm{~m}$., Decl. $29^{\circ} \mathrm{O}^{\prime} \mathrm{N}$. It seems probable that this object is the expected comet of Olbers.

\section{ASTRONOMICAL PHENOMENA FOR THE} WEEK I887 SEPTEMBER 4-Io.

(FOR the reckoning of time the civil day, commencing at Greenwich mean midnight, counting the hours on to 24 , is here employed.)

\section{At Greenwich on September 4}

Sun rises, 5 h. $19 \mathrm{~m}$.; souths, 1 ih. $58 \mathrm{~m} .58 \cdot 3 \mathrm{~s}$. ; sets, $18 \mathrm{~h} .39 \mathrm{~m}$. decl. on meridian, $7^{\circ} 13^{\prime}$ N.: Sidereal Time at Sunset, I 7 h. $33 \mathrm{~m}$.

Moon (at Last Quarter Sept. 10, 15 h.) rises, 19 h. $25 \mathrm{~m} .{ }^{*}$; souths, Ih. $9 \mathrm{~m}$. ; sets, $7 \mathrm{~h} .4 \mathrm{~m}$. ; decl. on meridian, $3^{\circ} 39^{\prime} \mathrm{S}$.

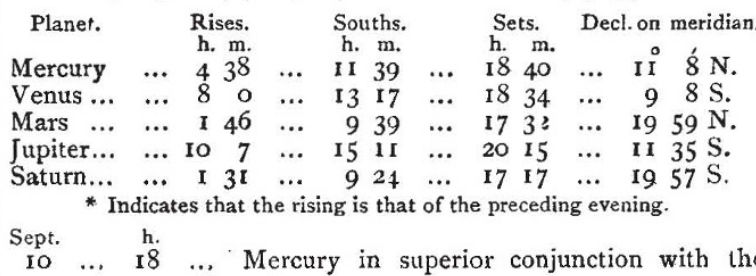
Sun. 


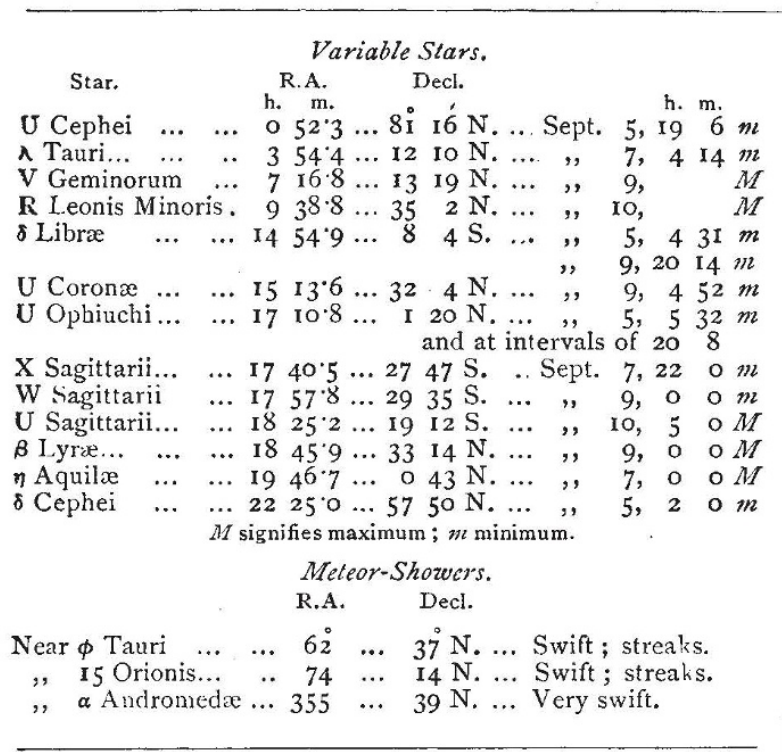

\section{SOCIETIES AND ACADEMIES. \\ PARIS.}

Academy of Sciences, August 22.-M. Janssen in the chair. -On the eclipse of August 19, by M. J. Janssen. The reports received from the various stations in European Russia and Prussia are generally described as unfavourable, owing to the clouded state of the weather at the critical time. A telegram, however, from M. Stanoiewitch states that at the Petrovsk station it was clear enough to take some photographs and to make a few observations. Much regret is expressed that so few observers could be induced to visit the Siberian stations, where much more successful studies might have been made.-On the cooling of the terrestrial crust, by M. Faye. This is a protest against the Rev. Ch. Braun, who, in his recent work on "Cosmogony from the Stand-point of Christian Science," adopts without acknowledgment the author's fundamental theory that the chilling process goes on more rapidly and more deeply under the seas than under the continents. M. Faye complains that M. Braun refers to him by name when criticizing his views, but omits to do so when adopting and reproducing them. - Solution of a problem, by M. J. Bertrand. Supposing a scrutiny of the ballot for two candidates, $\mathrm{A}$ and $\mathrm{B}$, the number of voters being $\mu$; A, the successful candidate, obtaining $m$ and B $\mu-m$ votes, what is the probability that during the scrutiny the number of votes for A will throughout exceed those of his rival? A rigorously algebraic solution is given of this problem, and it is added that the re-ult may perhaps be shown in a more direct way. Thus, if the number of voters be sixty, the successful candidate must have obtained forty-five votes in order that the probability of keeping the majority throughout the scrutiny be equal to $\frac{1}{2}$.Remarks accompanying the presentation of a memoir on the means of avoiding collisions at sea, by M. Moise Lion. The author considered that optical signals of great intensity could alone present sufficient guarantees of penetration in foggy weather. On board ships in motion the warning signal should consist of an electric focus projecting its light obliquely to the horizon and revolving round a vertical axis. He insists on the great advantage of imparting to the light an oscillatory motion in order to increase its luminosity. - On the partial lunar eclipse partly visible at Orgères (Eure-et-Loire) on August 3, by $M$. Edm. Lescarbault. 'The shadow cast on the upper left part of the moon was almost black; but to the left, and especially to the right, there were noticed two curvilinear triangles of $2^{\prime} \cdot 5$ to $3 \cdot 5$ length at base, where the shadow was ruddier than a very deep maroon. The triangle to the left was even darker than that to the right, while both were connected by a thin streak of the same colour, but deeper to the south of the moon. The inner edges of these maroon surfaces blended insensibly in the black shadow, and within them could be very faintly distinguished a few cirques, which could not be otherwise accurately determined. On the disk the shadow was edged with a grayish straw-coloured band, two and a half or three times as broad as
Tycho, the common edge of this band and of the shadow being somewhat sharply traced.--On the coefficient of self-induction of two bobbins combined in quantity, by MM. G. Maneuvrier and P. Ledeboer. In a previous paper the authors dealt with the problem whether from the stand-point of self-induction it was possible to compensate two bobbins combined in quantity by a single bobbin, and consequently whether it might be possible to assign to such a system a determined coefficient of self-induction in the strict sense of the term. A fresh series of experiments are here described which have been carried out for the purpose of determining how far the results already obtained may be approximately verified for the most general case. These experiments lead to the conclusion that for the general case the system of two bobbins cannot be compensated by a single bobbin, and consequently that such a system has no coefficient of selfinduction properly so called.-On the compressibility of some solutions of gas, by M. F. Isambert. From the experiments here described the author infers that a simple solution of gas changes : very little the coefficient of compressibility of the solvent ; further that the solution of ammoniac gas in water behaves in the same way as that of a true chemical compound. -On the titanates of zinc, and more particularly on a trititanate, by M. Lucien Lévy. Metallic titanates are ohtained either by the action of the metallic oxide on the titanic acid in the presencc of the chloride or the fluoride, or else by the action of a mixture of the metallic sulphate and an alkaline sulphate on the same acid. Applied to the production of the titanates of zinc these two processes bave yielded different results. The first, which is here more specially dealt with, leads in general to a trititanate. The second, on the contrary, furnishes several salts according to the proportions employed.

BOOKS, PAMPHLETS, and SERIALS RECEIVED.

Science and Art Schools and Classes Directory, 1887 (Eyre and Spottis. woode)- - Calendar of Durham College of Science, Newcastle-on-Tyne, 1887-88 (Newcastle-on-Tyne).-Insects Noxious to Agriculture and Plants in New Zealand: The Scale Insects: W. M. Maskell (Wellington).Electrical Distribution by Alternating Currents and Transformers: R,
Kennedy (H. Alabaster and Co.). - Proceedings of the Liverpool Naturalists' Kernedy (H. Alabaster and Co.).-Proceedings of the Liverpool Naturalists
Field Club, r886-87 (Liverpool).-Economic Furestry : Prof. Boulger.Field Club, r886-87 (Liverpool). - Economic Furestry: Prof. Boulger--
Transactions and Proceedings of the New Zealand Institute, 1886 , vol. xix. Transactions and Proceedings of the New Zealand Institute, 1886, vol. xix.
(Wellington).-Quarterly Journal of the Geological Society, vol. xliii. Part 3 , (Wellington).-Quarterly Journal of the Geological Society, vol. xliii. Part 3,
No. x71 (Longmans) - Journal of Physiology. vol. viii. Nos. 3 and 4 (Cambridge). - Annalen der Physik urd Chemie, I887, No. 9 (Barth, Leipzig) Quarterly Journal of Microscopical Science, August (Churchill). - The Asclepiad, No. $x_{5}$, vol. iv. : Dr. B. W. Richardson (Longmans).

\section{CONTENTS.}

PAGE

\section{Higher Algebra}

Our Book Shelf :-

Sexton: "Outlines of Quantitative Analysis" . . . 4to Fresenius: "Qualitative Chemical Analysis" . . . 4I I Carnelley : "Melting and Boiling Point Tables" . . 4II

\section{Letters to the Editor:-}

The Law of Error.-J. Venn. (With Diagrams) - $4 \mathrm{II}$ The Sense of Smell in Dogs.-J. M. H. . . . 412 Electricity of Contact of Gases with Liquids.-Prof. Oliver J. Lodge, F.R.S. . . - * '

The Lunar Eclipse of August 3.-M. C.; H. P. Malet rajd By Capt. W. J. L. Wharton,
Masámarhu Island. The Owens College Natural History Buildings. (Illustrated) A - is iation

Inaugural Address by Sir Henry E. Roscoe, M.P. D.C.L., LL.D., Ph.D., F.R.S., V.P.C.S., President

Section A.-Mathematical and Physical Science.Opening Address by Sir Robert S. Ball, L L.D. F.R.S., President of the Section . . . . . 424

Notes A . . . . . . 429

Variable Star in the Ring Nebula in Lyra . . . . . 43I

New Variable Star ......... . . 43I

Discovery of a Comet.. .4431 Astronomical Phenomena for the Week 1887 September 4 -10 . . . . . . . . 4 431 Societies and Academies Books, Pamphlets, and Serials Received . . 432 